\title{
Exploring The Effects Of Social Exchange Relationships On The Scholarly Productivity Of New Faculty Members In Accounting
}

\author{
Joseph C. Ugrin, Kansas State University, USA \\ Marcus D. Odom, Southern Illinois University, USA \\ J. Michael Pearson, Southern Illinois University, USA \\ Tammy R. Bahmanziari, Middle Tennessee State University, USA
}

\begin{abstract}
This paper explores how social relationships between new accounting faculty members and their former dissertation chairs can influence the publishing productivity of the new faculty members in their early academic careers. The focus on social relationships offers a unique approach to studying the effectiveness doctoral education. Our findings show that strong social exchange between new faculty members and their former chairs can have a significant impact on new faculty members' scholarly productivity and provide some reasons for those effects. We also find differences in relationships between mixed and same gender pairs and examine reasons for those differences.
\end{abstract}

Keywords: Mentoring; Social Exchange; Leader-Member Exchange; Doctoral Education

\section{INTRODUCTION}

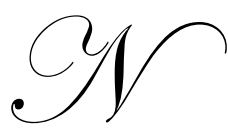

ew faculty members are under tremendous pressure to publish research in order to achieve promotion and tenure; an obstacle that new faculty members are initially confronted with during their third year and ultimately must overcome during their sixth year of employment. We contend that the publishing productivity of new faculty members is influenced by the relationship they forged with their dissertation chair while receiving their doctoral training. During a doctoral program, a chair's role can take on many forms and encompass more than just supervising the dissertation. A chair also serves as a mentor whose influence can span long into their doctoral student's career as a faculty member (Leach et al., 2007).

Mentoring is one of a number of factors that have been shown to influence faculty productivity. Positive mentoring relationships between doctoral students and their doctoral advisors have been shown to be important in degree completion and academic job placement and appear to carry on into the careers of graduates as evidenced by mentoring's effect on graduates' development and assimilation into the academic field (Blackburn et al., 1981; Lovitts, 2001; Weiss, 1981). In addition, continued co-authoring with a productive chair has been shown to have positive effects on the long-term research productivity of new faculty members (Leach et al., 2007). The value of mentoring seems hard to dispute but there tends to be differences across disciplines (Golde and Dore, 2001) and mentoring has many facets. A recent study attempted to look at one facet of mentoring that has been shown to be influential in workplace settings but has been overlooked in the academic setting (Ugrin, Odom, and Pearson, 2008); that factor is social exchange. Ugrin et al. (2008) found that strong social exchange between new faculty members and their former doctoral chairs relate to more publications by new faculty members early in their career. However, their reasons for the relationship were speculative and lacking in empirical evidence.

This study takes a more detailed look at social exchange by examining how and why social exchange has an impact on new faculty members' scholarly activities. We surveyed 41 new faculty member/former dissertation chair dyads to examine their social exchange, its effects on the new faculty members' scholarly productivity in their first six years of academic employment, and reasons for the effects. Our findings show that strong social exchange 
between new faculty members and their former dissertation chairs can have a significant impact on new faculty members' scholarly productivity early in their career and, that relationship is mediated by the ongoing nature of the relationship. We also find differences in the relationships between mixed and same gender pairs and examine reasons for those differences.

We expect that the results will be of interest to those that research social exchange by showing how social exchange can influence professional outcomes but those effects are influenced by other factors and the makeup of the dyad. We also suspect that the results will be of interest to those involved in doctoral education who are looking for ways to improve the education of their students.

\section{MENTORING AND SOCIAL EXCHANGE}

Mentors can be defined as experts or highly qualified individuals who are dedicated to helping a mentee with advice and direction. Mentoring can take place in many settings and take on many forms but in all cases, the mentor passes on expertise, provides direction, and/or gives guidance. These interactions can affect the future direction and decisions of the mentee and many times these interactions provide a roadmap for their success or failure.

In an educational setting, mentoring has been associated with increased scholarly productivity when new faculty members are paired with senior faculty members at their institution (Boice, 1992) but not all universities have these types of mentoring programs in place and the scholarly activity performed during a new faculty member's first few years often stems from doctoral program studies and the dissertation process. Strong mentoring relationships between doctoral students and their chairs have been linked to more scholarly productivity from doctoral graduates (Blackburn et al., 1981) but that literature is confounded with alternative explanations. For example, when examining the connection between mentoring and new faculty members' scholarly productivity, Blackburn et al. (1981) do not control for factors like the productivity level of the chairs, collaboration between new faculty members and former chairs on projects beyond the dissertation, new faculty members' ultimate place of employment, or other employment related factors such as teaching load, committee assignments, funding, graduate student support, or merely the type of institution new faculty members are employed at (e.g. doctoral granting or non-doctoral granting) ${ }^{1}$. Ugrin et al. (2008) recently found a link between the social exchange component of mentoring relationships between new faculty members and their former doctoral chairs but they also failed to control for many of the potentially confounding factors mentioned and failed to answer questions as to why social exchange is influential.

Ugrin et al. (2008) introduced leader member exchange (LMX), a commonly used measure of social exchange, to the educational literature. In other settings outside of academia, LMX has been associated with a number of positive outcomes such as increased trust between mentors and mentees (Graen, 1976; Klien and Kim, 1998), increased effort from employees (Graen et al., 1983), extra attention and help from mentors (Sidhu, 1988), and reduced stress amongst mentees (Harris and Kacmar, 2006). All of these outcomes would seemingly translate to academic settings and benefit new faculty members as well. As such, we conjecture that new faculty members that have stronger LMX with their former doctoral chairs will have greater degrees of success relative to those with weaker LMX relationships. After completion of their doctoral programs, new PhDs, upon accepting their first faculty appointment, should continue to reap the benefits of a strong relationship well into their academic careers. This leads to our first research question which asks if stronger LMX between doctoral students and their dissertation chairs leads to a greater number of publications in students' first six years of academic employment as new faculty members.

RQ1: Do new faculty members that have stronger social exchange with their former dissertation chairs have more publications in their first six years of academic employment then those that have weaker social exchange?

\footnotetext{
${ }^{1}$ New faculty members that are employed at institutions that require a higher number of publications for tenure, such as doctoral granting institutions, may have greater scholarly productivity out of necessity regardless of relationships.
} 
Two plausible explanations for the relationship between LMX and new faculty members' scholarly productivity are; (1) the amount of research new faculty members and their dissertation chairs started/collaborated on during new faculty members' $\mathrm{PhD}$ programs and, (2) the degree to which relationships continued past $\mathrm{PhD}$ program completion into the new faculty members' academic appointment. The ensuing discussion explains our propositions.

Research has shown that doctoral student/dissertation chair (DS/DC) collaboration leads to a greater number of submissions during doctoral programs (Green and Bauer, 1995). We suspect this may spill over into the early careers of new faculty members. We propose that when social exchange is high, DS/DC relationships will flourish and have a greater likelihood of continuing beyond the doctoral program. These DS/DC relationships will transform into new faculty member/former chair (NF/FC) relationships and provide a positive influence on the early careers of new faculty members and result in more publications. The literature on leader member exchange has shown that LMX correlates positively with factors like commitment, altruism, loyalty, and retention (Gerstner and Day, 1997; Schriesheim et al., 1999) and a related study on mentoring in academics by Zhao, Golde, and McCormick (2007) found that a more personal touch by a chair serving as a mentor results in higher satisfaction in the DS/DC relationship and suggests that strong social relationships advance the mentoring process and have positive effects on students when they become new faculty members. As such, we propose that social exchange influences scholarly productivity via two factors, (1) collaboration during the doctoral program and, (2) continuation of the relationship after the doctoral program. The effects of collaboration have been illustrated (Green and Bauer, 1995) and logic would suggest that collaboration will continue beyond the doctoral program if the relationship is strong. This leads to the next set of research questions:

RQ2a: Does the amount of collaboration on research between doctoral students and their dissertation chairs during $\mathrm{PhD}$ programs mediate social exchange's effect on the quantity of publications in the early career of new faculty members?

RQ2b: Does continued collaboration between new faculty members and their former dissertation chairs beyond the $\mathrm{PhD}$ program mediate social exchange's effect on the quantity of publications in the early career of new faculty members?

We also question if the value new faculty members place on their relationship with their dissertation chairs influence how social exchange affects collaboration, continuation of the relationship, and eventually publishing productivity. In other words, does high social exchange influence the outcome variables studied here to a greater degree when the new faculty members value their former dissertation chair more? Social exchange theory posits that social interactions are a rational process based on economic calculus (Blau, 1964). One will seek out relationships, put effort into fostering them, and act in the interest of others when reciprocity is anticipated. This may be particularly true in the individualistic and goal related field of academia. We expect that more effort will be put forth to continue relationships that are expected to bear fruit. We study this issue by examining how the value new faculty members place on their former dissertation chairs' abilities to advance their research agendas affects (1) the relationship between social exchange and the continuation of new faculty member/former dissertation chair (NF/FC) relationships and, (2) the relationship between social exchange and research collaboration. This leads into research questions $3 \mathrm{a}$ and $3 \mathrm{~b}$ :

RQ3a: Is the effect of social exchange on the amount of collaboration between doctoral students and their dissertation chairs during the $\mathrm{PhD}$ program enhanced by the value doctoral students report to have placed on their dissertation chairs' abilities to advance their future research agendas?

RQ3b: Is the effect of social exchange on continued collaboration beyond the $\mathrm{PhD}$ program enhanced by the value new faculty members place on their former chairs' abilities to advance their research agendas?

\section{GENDER AND SOCIAL EXCHANGE}

Theorists have argued that dyads of similar demographics should have higher social exchange but previous studies on the topic have provided mixed results. Ragins (1997) suggests that the makeup of a mentoring 
relationship influences the type of assistance provided by the mentor, which has an influence on mentee outcomes. Acting as mentors, $\mathrm{PhD}$ dissertation chairs can be role models, friends, and career counselors. All are important roles, but all potentially affect doctoral students in different ways. Other researchers have suggested that homogeneous dyads should be more successful because of shared identity and interpersonal comfort for both parties which in turn results in increased role modeling by the mentee and increased support by the mentor (Sosik and Godshalack, 2000). However, the arguments have little empirical backing, and the results of existing studies are equivocal (e.g. Koberg, Boss, and Goodmand, 1998; Ensher and Murphy, 1997; Ragins and Cotton, 1991, 1999; Allen and Eby, 2004). The mixed results also include studies using LMX as a measure of social exchange. For example, in their study of demographic variables on relationships, Tsui and O'Reilly (1989) found that homogeneity of gender had a positive effect on LMX relationships yet Basu and Green (1995) and Ugrin et al. (2008) did not. In addition to being inconclusive, these studies take place in an organizational context with the exception of Ugrin et al. (2008). In reaction to the uncertainty about demographics, this research looked at the effects of gender on social exchange to address the following research question:

RQ4: Do same gender dyads have higher social exchange relative to mixed gender dyads?

One explanation for equivocal results pertaining to gender and other demographics could be that mentees often perceive roles based on stereotypes. Congruent with social role theory (Eagly, 1987), entrenched stereotypes may lead people to believe that underrepresented groups, particularly women, have less power and are less qualified than they actually are (Broverman et al., 1972; Schein, 1973). Kimmel (2004) suggests that traditional social stereotypes still permeate through academic institutions. As such, female mentors may be unjustifiably undervalued. Based on this, we question if new faculty members will report to have placed a higher value on their relationships with male chairs, perceiving they have more power and can more effectively help their students advance their career agenda. This leads into research question five:

RQ5: Do new faculty members report to perceive a greater value in relationships with male dissertation chairs relative to relationships with female dissertation chairs?

\section{METHODOLOGY}

\section{Sampling, Data Collection, and Descriptive Statistics}

The target population consisted of accounting faculty at U.S business schools. The new faculty members that were selected were required to be at least six years out of their doctoral program, but not so far out that the time frame would prevent them from recalling the type of relationship they had with their dissertation chair. Therefore, the sampling frame was limited to faculty members that graduated with their doctorate between 1990 and $2000^{2}$.

The eventual sample was selected via the following procedure. Potential participants were identified through an online vita search of accounting PhD programs. Senior faculty members (chairs) were selected first. If a senior faculty member's vita was available online and included a list of former doctoral students that included students who graduated within our specified time frame, the senior faculty member was included in our initial sample. Effort was made to retain homogeneity in numbers between tiers of accounting $\mathrm{PhD}$ granting institutions using the rankings presented by Glover, Prawitt, and Wood (2006) as a guideline. A total of 35 senior faculty members were randomly selected, 18 from tier 1 institutions and 17 from tier 2 and tier 3 .

The senior faculty members were then contacted by email asking for their participation. If they agreed to participate, they completed an online mentor survey for each of their former $\mathrm{PhD}$ students (the new faculty members). Once a dissertation chair responded, an email was sent to his/her former doctoral student(s) asking them to complete a corresponding online survey. We also requested that the responding former chairs forward an email to their former doctoral students indicating their participation in the project. Code numbers were used to link the former students' and chairs' responses. Due to the sensitivity of the data, it was clearly indicated to both parties that data linking participants would be confidential.

\footnotetext{
${ }^{2}$ Data was collected in 2007.
} 
Responses were collected from 25 senior faculty members representing 18 universities and from 44 new faculty members, representing 2.5 percent of the graduates from 1990 to 2000 (Bouillon and Ravenscroft, 2010). Data from three sets of respondents was deleted due to incompleteness. In all, the data collection yielded 41 usable dyads with 16 coming from tier 1 institutions, 16 coming tier 2 institutions, and 9 coming from tier 3 institutions. The data represented faculty members working at various types of institutions (e.g. new faculty member responses came from 13 doctoral granting institutions, 28 non-doctoral granting institutions, and 1 not reporting) with a wide range of publishing activity (e.g. 1 to 13 total publications amongst new faculty members and an average number of publications ${ }^{3}$ per year amongst former chairs of .38 to 2.87). We also collected data related to other factors that we anticipated would influence new faculty members' publishing activity, including the new faculty members' selfreported number of committee assignments during their first six years of academic employment, teaching load, financial assistance, and a rating of the research abilities of their colleagues during this time. Table 1 gives detail about the sample, including the makeup of the dyads.

Table 1: Descriptive Statistics

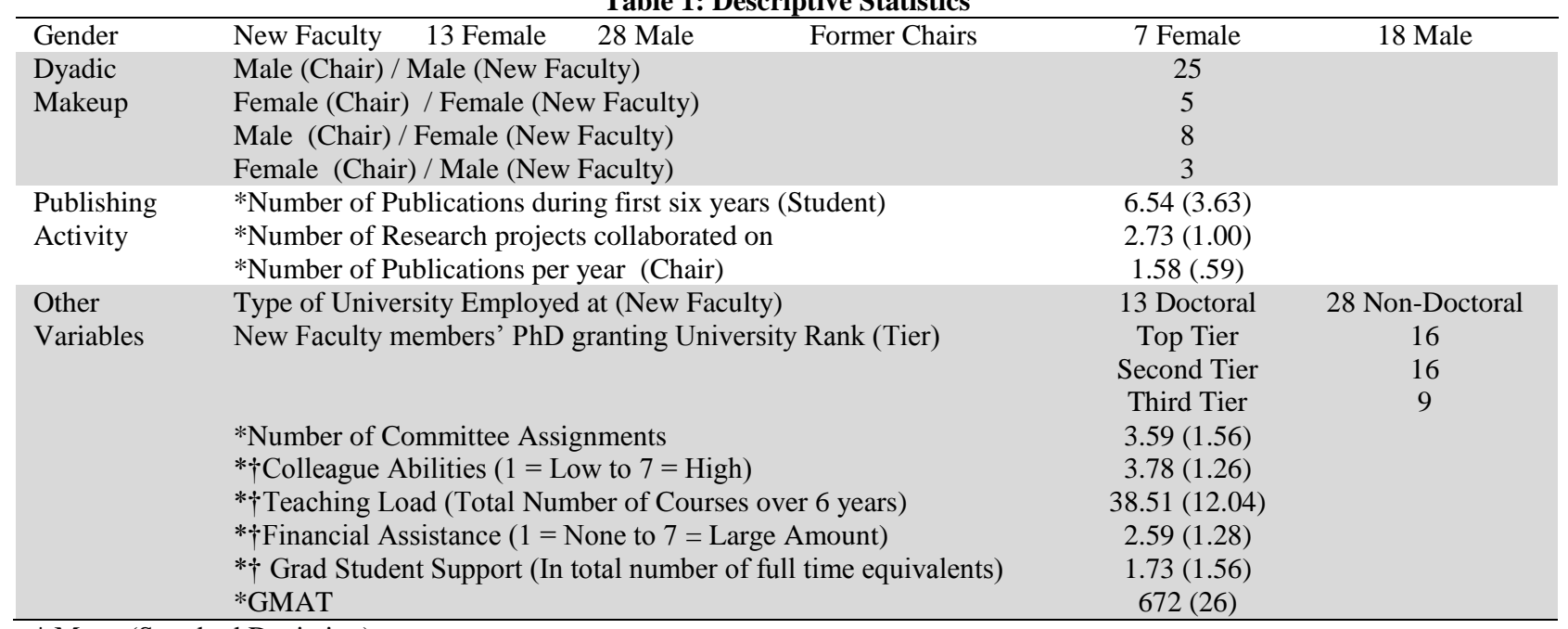

* Mean (Standard Deviation)

$\uparrow$ Correlated significantly with the Type of University Employed

\section{Measurement}

Consistent with Ugrin et al. (2008), we elected to use leader member exchange (LMX) as our measure of social exchange because it reflects the perspective of both parties. LMX measures the social relationship between a mentor (former chair) and mentee (new faculty member) by seeking responses from both and summing results into a composite score for the dyad (Dansereau, Graen, and Haga, 1975). A five item version developed by Ugrin et al. (2008) for use in the academic setting was utilized and was retested for consistency and reliability. Chronbach Alphas were computed at .840 for the mentee version using the 41 new faculty member participants and .813 for the mentor version using the 25 senior faculty participants, indicating overall reliability and consistency for use as a measurement of LMX in this setting. The questions are displayed in the appendix A.

New faculty members' scholarly activity was measured by the number of peer reviewed publications in their first six years of employment. The continuation of the new faculty/former chair (NF/FC) relationship was measured by one Likert scaled item posed to the new faculty members that asked how much they have continued the relationship. The amount of research collaborated on during the new faculty members' $\mathrm{PhD}$ programs were measured using one item. How new faculty members valued their former chair for research guidance was also measured by one Likert scaled item. A summary of the main variables is presented in the appendix A.

\footnotetext{
${ }^{3}$ Publishing activity amongst chairs was converted to average number of publications per year to account for varying lengths of employment.
} 


\section{DATA ANALYSIS}

\section{Preliminary Correlation Analysis}

We performed a preliminary correlation analysis of potential covariates. First, a self-reported GMAT score was collected to control for new faculty members' abilities; it was not significantly correlated with outcome variables and not included in further analyses. A test of the tier of institution the new faculty members received their $\mathrm{PhD}$ from did not find any significant correlation between the tier of new faculty members $\mathrm{PhD}$ schools and new faculty members' quantity of publications in their first six years of employment. There were also no differences in the LMX scores, the value the new faculty members placed on their former chairs, or the amount of collaboration between the new faculty and their former chairs across tiers. Thus the tier of University in which the new faculty received PhDs was also not included in further analysis. Congruent with Glover et al. (2006), the new faculty members' quantity of publications was correlated $(\mathrm{p}<.05)$ with the type of institution they were initially employed at (doctoral granting versus non-doctoral granting). The data related to teaching load, financial assistance, and graduate student support was significantly correlated with the type of institution at which the new faculty members were employed. Thus for parsimony, only the type of institution new faculty members were employed at was included in further analyses. It seems worthy to note that former chair reputation and the quality of the new faculty members' and former chairs' publications were not considered due to concerns over the subjectivity and validity of measurement. A correlation matrix of variables included in further analyses is presented in Appendix B.

\section{Tests of Research Questions}

Due to the exploratory nature of the study, a stepwise regression was initially performed to test research question one using the number of refereed publications the new faculty members had in their first six years of academic employment (PUBLICATIONS) as the dependent variable, and all other variables from Table 2 as the independents. The regression retained the new faculty members' reported value in their former chairs ability to help advance their research agenda (VALUE) $(\mathrm{p}<.05)$, the type of institution the new faculty members were employed at (JOB_TYPE) $(\mathrm{p}<.05)$, and the amount of collaboration between the new faculty members and their former chairs during the PhD program (COLLABORATE) $(\mathrm{p}<.05)$ (Table 2). Although LMX was not retained as a significant predictor of publishing productivity, that may be due to the relationships mentioned in RQ2a(b) and RQ3a(b) where social exchange would seemingly have an indirect effect on productivity through other variables. Those indirect effects are examined in the remaining tests.

Table 2: Stepwise Regression Results for Research Question 1 (Items Retained)

\begin{tabular}{|c|c|c|c|c|c|}
\hline & \multicolumn{2}{|c|}{ Unstandardized Coefficients } & \multirow{2}{*}{$\begin{array}{c}\begin{array}{c}\text { Standardized } \\
\text { Coefficients }\end{array} \\
\text { Beta } \\
\end{array}$} & \multirow{2}{*}{$\mathbf{T}$} & \multirow{2}{*}{ Sig. } \\
\hline & $\mathbf{B}$ & Std. Error & & & \\
\hline (Constant) & -.580 & 1.509 & & -.384 & .703 \\
\hline VALUE & .771 & .256 & .378 & 3.018 & .005 \\
\hline JOB_TYPE & 2.670 & .942 & .347 & 2.833 & .007 \\
\hline COLLABORATE & 1.111 & .453 & .306 & 2.451 & .019 \\
\hline
\end{tabular}

Dependent Variable: Publications

Adjusted $\mathrm{R}^{2} .409$

Research question 2a was examined by a test of mediation between LMX and PUBLICATIONS via COLLABORATE. We performed two complementary tests of mediation. First, we followed the steps outlined in Baron and Kenney (1986). The results revealed that LMX had an influence on PUBLICATIONS, via COLLABORATE. LMX was significantly related to COLLABORATE $(\mathrm{p}<.05)$ and COLLABORATE was significantly related to PUBLICATIONS $(\mathrm{p}<.05)$. A significant relationship existed between LMX and PUBLICATIONS (path P31), but when including COLLABORATE in the model (path P31'), the relationship between LMX and PUBLICATIONS was no longer significant (the unstandardized coefficient changed from .204 (p 
$<.05$ ) on path $\mathrm{P} 31$ to .139 ( $\mathrm{P}>.05)$ on path $\mathrm{P} 31$ '), suggesting COLLABORATE mediates the relationship (Figure $1)$. Mediation was also confirmed by a Sobel test $(\mathrm{p}<.05)$.

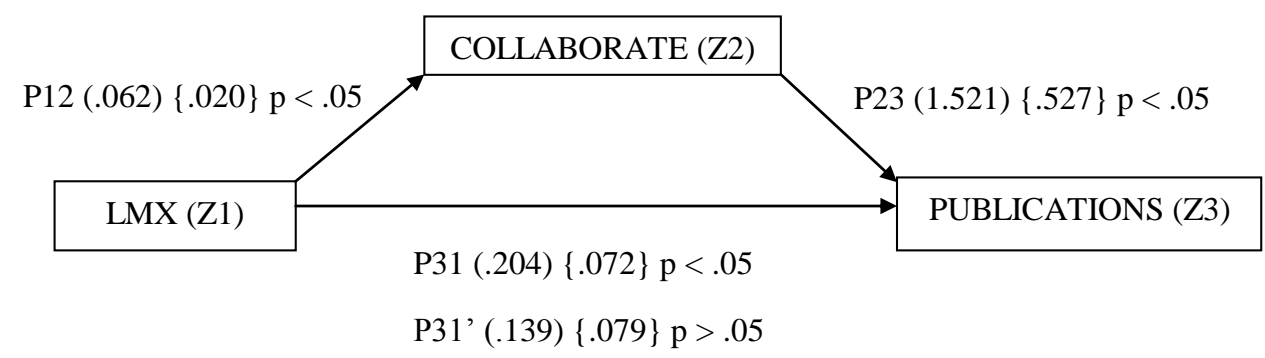

(Regression Coefficient $)\{$ Standard Error $\} \quad$ Sobel Test $(\mathrm{p}<.05)$

Figure 1: Mediating Effect of Collaboration During the PhD Program on LMX's Relationship with New Faculty Members' Publishing Activity (Research Question 2a)

Research question $2 \mathrm{~b}$ was examined by a test of mediation between LMX and PUBLICATIONS via the continuation of the mentoring relationship (CONTINUE). LMX was significantly related to CONTINUE $(\mathrm{p}<.05)$ and CONTINUE was significantly related to PUBLICATIONS $(\mathrm{p}<.05)$. The test results revealed that LMX also had an influence on PUBLICATIONS, via CONTINUE. A significant relationship existed between LMX and PUBLICATIONS (path P31), but when including CONTINUE in the model (path P31'), the relationship between LMX and PUBLICATIONS was no longer significant (the unstandardized coefficient changed from .204 ( $\mathrm{p}<.05$ ) on path P31 to .045 ( $\mathrm{P}>.05$ ) on path P31'), suggesting CONTINUE mediates the relationship (Figure 2). Mediation was also confirmed by a Sobel test $(\mathrm{p}<.05)$.

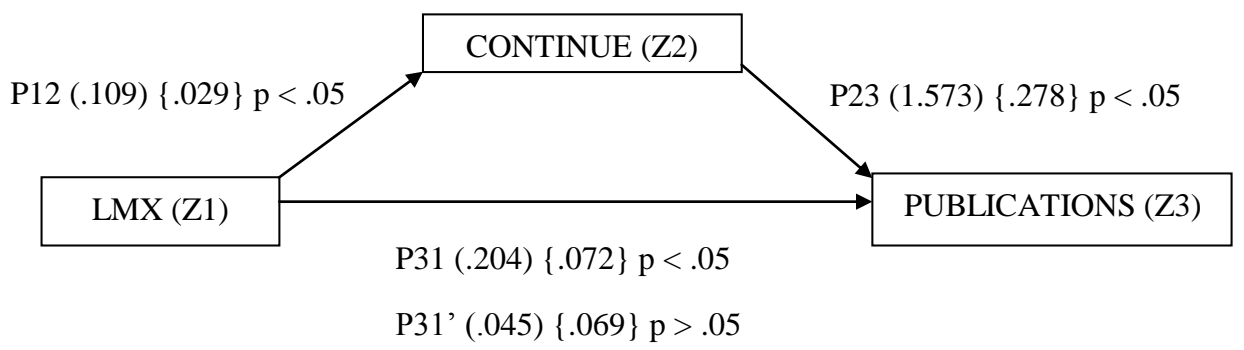

(Regression Coefficient) $\{$ Standard Error $\} \quad$ Sobel Test $(\mathrm{p}<.05)$

Figure 2: Mediating Effect of Continuation of the Mentoring Relationship on LMX's Relationship with New Faculty Members' Publishing Activity (Research Question 2b)

A mediation test was not performed for research question 3a since VALUE did not correlate significantly with COLLABORATE (see Table 2). As such, no mediation could take place ${ }^{4}$. A test of mediation for research question $3 \mathrm{~b}$ revealed a relationship between LMX and CONTINUE and that relationship was partially mediated by VALUE (Figure 5). LMX was significantly related to VALUE $(\mathrm{p}<.05)$ and VALUE was significantly related to CONTINUE $(\mathrm{p}<.05)$. A significant relationship existed between LMX and CONTINUE (path P31), but when

\footnotetext{
${ }^{4}$ Note, we also tested moderation of LMX on COLLABORATE in a separate regression but the interaction term was not significant $(\mathrm{p}>.05)$
}

(C) 2012 The Clute Institute http://www.cluteinstitute.com/ 
including VALUE into the model (path P31'), the relationship changed significantly (the unstandardized regression coefficient changes from .109 in path P31 to .096 in path P31'; $\mathrm{z}>44.394$ ) suggesting mediation. However, LMX still remained a significant predictor of CONTINUE when VALUE was included in the model, suggesting VALUE only partially mediates the relationship (Figure 3).

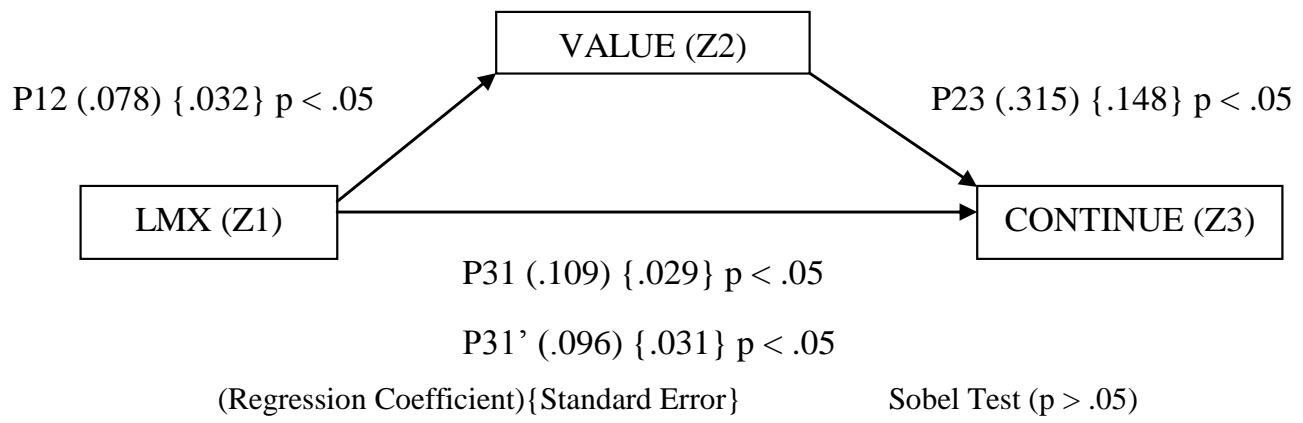

Figure 3: Mediating Effect of New Faculty Members' Value in their Chair on LMX's Effect on the Continuation of the New Faculty Member/Former Chair Relationship

An independent samples t-test was performed to analyze research question four (Levene's test for equality of variance was not significant for gender $(\mathrm{p}>.05)$ ). The statistical analysis failed to show that dyads consisting of new faculty members and former chairs of the same or opposite sex had LMX scores that were statistically different from one another $(\mathrm{p}>.05)$. The mean LMX score for opposite gender dyads in the sample was 56.82 and the mean LMX score for same gender dyads in the sample was 54.07 (Table 3). A follow up ANOVA using each type of dyadic pair (female chair/female student; female chair/male student; male chair/female student; male chair/male student) as the independent variable also failed to show differences in LMX scores ( $p>.05)$.

Table 3: T-Test Results for Research Question 4

\begin{tabular}{lcccccc}
\hline Independent Variable & $\begin{array}{c}\text { Dependent } \\
\text { Variable }\end{array}$ & $\begin{array}{c}\text { Mean } \\
\text { Difference }\end{array}$ & $\begin{array}{c}\text { Std. Error } \\
\text { Difference }\end{array}$ & t & Sig. \\
\hline *RQ4 & Gender (Same vs. Different) & LMX & 2.75 & 2.57 & 1.070 & .291 \\
\hline * Same Gender = 30 (Mean LMX, 54.07); Mixed Gender = 11 (Mean LMX 56.82) & & &
\end{tabular}

An independent samples t-test was performed to analyze research question five using VALUE as the dependent variable and GENDER as the independent. The results failed to show any greater value placed on chairs of either gender $(\mathrm{p}>.05)$ (Table 4$)$.

Table 4: T-Test Results for Research Question 5

\begin{tabular}{llccccc}
\hline & Independent Variable & $\begin{array}{c}\text { Dependent } \\
\text { Variable }\end{array}$ & $\begin{array}{c}\text { Mean } \\
\text { Difference }\end{array}$ & $\begin{array}{c}\text { Std. Error } \\
\text { Difference }\end{array}$ & S & Sig. \\
\hline *RQ5 & Gender of the Chair & $\begin{array}{c}\text { VALUE for } \\
\text { Research } \\
\text { Guidance }\end{array}$ & .985 & .613 & -1.608 & .116 \\
\hline
\end{tabular}

* Female Chair $=8($ Mean Value 3.500); Male Chair $=33($ Mean Value 4.485)

We also followed this t-test for research question five with an ANOVA. When dyad makeup (female chair/female student; female chair/male student; male chair/female student; male chair/male student) served as the independent variable and VALUE as the dependent variable, the results revealed that VALUE was significantly 
related to the makeup of the dyad $(\mathrm{p}<.05)$. A post-hoc test comparing the dyads revealed that new female faculty members had a higher perceived VALUE in male former chairs. There were no significant differences in how new male faculty members perceived the VALUE of either male or female former chairs (Table 5).

Table 5: Comparisons of New Faculty Members' Perceived Value in their Former Chair by Dyadic Makeup

\begin{tabular}{|l|c|c|c|}
\hline Dyadic Make Up & N & \multicolumn{2}{|c|}{ Subsets } \\
\hline Chair/New Faculty & 5 & 3.2000 & Subset 2 \\
\hline Female/Female & 25 & 4.0000 & 4.0000 \\
\hline Male/ Male & 3 & 4.1200 & 4.1200 \\
\hline Female/Male & 8 & & 5.6250 \\
\hline Male/Female & & & \\
\hline
\end{tabular}

*Tukey HSD

\section{DISCUSSION}

The findings suggest that social exchange between new faculty members and their former dissertation chairs can have an important role in the research productivity of the new faculty members by showing a positive relationship between social exchange amongst new faculty members and their former dissertation chairs and the number of peer reviewed publications obtained by the new faculty members during their first six years of academic employment. This confirmed the findings of Ugrin et al. (2008) and Blackburn et al. (1981). However, our findings also show that the relationship between social exchange and research productivity is contingent on the amount of research the new faculty members and their former chairs collaborated on during the new faculty members' $\mathrm{PhD}$ programs and the continuation of their relationships after $\mathrm{PhD}$ programs.

We suspect that these findings should be relevant to individuals planning to pursue a $\mathrm{PhD}$ and to doctoral faculty and administrators. Considering that relationships appear to be highly important, students ought to pay attention to the type of relationship they anticipate having with their prospective chair since strong relationships tend to be more ongoing and can reward the new scholar in their early career. The findings may also be of interest to faculty and administrators who want to implement mechanisms to help facilitate and foster those relationships. Finding ways to allow potential doctoral students to meet and get to know senior faculty that could possibly serve as their dissertation chair could help them to begin to develop a relationship.

The findings fail to show a difference in LMX for same or mixed gender groups and they do not show any additional value placed by new faculty members on either male or female dissertation chairs in general. The follow up test did suggest that new female faculty members perceived greater value in chairs of the opposite gender. This is consistent with social role theory and the propositions of Kimmel (2004) that underrepresented groups, particularly women, are sometimes undervalued in academia. Differences in the way dissertation chairs are valued has powerful implications since the findings also suggest that the value placed on the dissertation chair by the new faculty member is one factor that mediates the relationship between social exchange and the continuation of their relationship beyond the $\mathrm{PhD}$ program.

\section{LIMITATIONS AND DIRECTIONS FOR FUTURE RESEARCH}

There are several limitations in this study. First, the sample size was small and limited the type of statistical analysis that could be performed. However, considering the nature of the study, individual tests of the research questions seem adequate.

We also do not have a clear proxy to control for new faculty members' abilities. We collected information related to the institution in which they obtained their $\mathrm{PhD}$ and separated them into tiers, yet that measure did not relate to the outcome variables. We suspect that the tier of the participants' $\mathrm{PhD}$ institution may relate significantly with publication in particular journals, but we are not surprised that it did not relate with participants' quantity of peer reviewed publications considering others have found similar results (Glover, 2006). We also collected GMAT scores and it did not relate to the outcomes and was not included in the analyses. GMAT was not influential because 
all doctoral students in accounting have a high GMAT score and there was not adequate variability in our results to separate our participants. In retrospect however, ability, aptitude, motivation, and attitude are typically identified by mentors when choosing a mentee and this may be reflected in exchange relationships and LMX scores (Kram, 1983; Graen and Scandura, 1987). Considering this perspective, a broader control for ability beyond participants' $\mathrm{PhD}$ program tier and GMAT may already be a facet of the LMX scores and thus controlled.

The sampling procedure is limited by self-selection and participant motivations. Although we initially selected the former dissertation chairs from randomly selected universities within each tier, only those that posted their curriculum vita with a list of former doctoral students were sampled and participation was voluntary. Often individuals participate only if they feel extremely strong towards the subject matter they are questioned about which could lead to responses being biased towards individuals with extremely positive or negative views of their relationship. Although the motivations of participants and reasons for posting (or not posting) vitas online cannot be assessed here, bias amongst those sampled can to some degree. Following a procedure outlined by Groves et al. (2004), selection bias was analyzed in a post-hoc comparison of known information about our final sample and the accounting faculty population at doctoral granting institutions and response bias was assessed by comparing known information about both the respondents and non-respondents.

To assess selection bias in our sample of dissertation chairs, we analyzed differences in gender and publishing productivity between our sample and the population. The population of accounting faculty at doctoral granting institutions is approximately $66 \%$ male and $34 \%$ female (AAA, 2008). Our sample was $72 \%$ male and $28 \%$ female yielding a slightly higher percentage of male participants but the difference was not significant $(\mathrm{p}>$ $.05)$. The publishing productivity of our sample of chairs averaged 1.58 publications per year $($ Std. Dev. $=.59)$. The productivity of tenured faculty at doctoral granting institutions averaged approximately 1.88 publications per year (Std. Dev. $=.35)$ (Glover et al., 2006). The mean difference in publishing productivity is not significantly different $(p>.05)$. These findings suggest that our sample of dissertation chairs is representative of the population, at least for gender and research productivity.

To assess response bias we analyzed differences in dissertation chairs that responded and did not respond across gender, average publications per year, and their school rank (top-tier, middle-tier, and third-tier). Chi-square tests did not yield any significant differences across the three factors (all $p>.05$ ). For the new faculty members, we analyzed gender, type of university they were employed at (doctoral vs. non-doctoral granting), and a ranking of the university they received their $\mathrm{PhD}$ (top-tier, middle-tier, third-tier) for differences between the responders and nonresponders. These Chi-square tests also failed to yield any differences (all $p>.05$ ). These tests suggest that those that responded are representative of the potential participants that were contacted and response bias is minimal.

As participants were required to recollect relationships and perceptions that took place at least six years prior, hindsight bias may have occurred. A future longitudinal study could shed additional light on the subject and overcome the limitations of our retrospective approach.

Another limitation is that we measured scholarly productivity by the number of peer reviewed publications without considering information related to publication quality. Future researchers may want to control for quality using measures such as journal rankings or the number of times participants' research is cited by others.

The measurement of several other variables is also limited. In particular, constructs that were not measured with multi-item scales may not precisely account for various facets of the construct and render it impossible to assess measurement reliability and sources of variability (Pedhauzur and Schmelkin, 1991). On the other hand, arguments exist for the use of single-item measures, and single-item measures are contended to be beneficial for practical purposes (Nagy, 2002). The literature also argues that single-item measurements can be appropriate when a construct has limited dimensions or is unambiguous (Wanous et al., 1997; Sackett and Larson, 1990). Of the items measured here, it seems that the pitfalls of single-item measures would have the largest potential impact on CONTINUE and VALUE since it would seem that relationships could be continued in a number of ways (e.g. personal versus professional) and how the new faculty members valued their former chairs could have several facets (e.g. the chair's ability to help with analyses, writing, topic or journal selection). However, these problems do not mean a measure is invalid (Wanous et al., 1997), they merely limit analyses and trade-offs exist between operational efficiency (a shorter survey) and single-item shortcomings. 
Finally, the study is limited to U.S. institutions and a follow-up from foreign universities would be interesting. For example, a follow-up in Europe might be particularly interesting considering Europe is also challenged by faculty shortages but has also been confronted with other issues stemming from differences in doctoral programs across nations which have resulted in difficulty transferring degrees between countries (Hartman and Pearson, 2010). These concerns have resulted in European reforms that target degree transferability and have resulted in a shift away from the traditional apprenticeship model to one that imposes more structure, resembling that of most American universities. In addition, many European universities have aimed for AACSB accreditation, accelerating their transition. If the pattern of results in this study hold true in Europe, European universities should be cautious as they move away from their traditional approach.

\section{CONCLUSION}

Despite the limitations, this study provides interesting insight into social exchange relationships and how they are an important facet of doctoral education. There is an important implication for doctoral students, doctoral faculty, and the academic profession; strong relationships can help produce new PhDs that are highly efficient researchers. Although being aware of social exchange may not help fix the doctoral faculty shortage in terms of numbers, it may help address the other underlying issue of scholarship.

\section{AUTHOR INFORMATION}

Dr. Joseph C. Ugrin is an Assistant Professor of Accounting at Kansas State University in Manhattan, KS. Dr. Ugrin has published papers in the Journal of Accounting and Public Policy, Accounting Horizons, International Journal of Accounting Information Systems, the Journal of Information Systems Education and other academic journals. He primarily researches behavioral issues in accounting and information systems. E-mail: jugrin@ksu.edu. Corresponding author.

Dr. Marcus D. Odom is a Full Professor, the Deloitte \& Touche Faculty Fellow, and serves as the Director of the School of Accountancy at Southern Illinois University. Dr. Odom has published papers in the Journal of Information Systems, International Journal of Accounting Information Systems, the Journal of Accounting and Public Policy, the Review of Accounting Information Systems, the Journal of End User Computing, the Journal of Applied Business Research, and other academic journals. He researches behavioral issues in accounting and information systems. E-mail: modom@cba.siu.edu

Dr. J. Michael Pearson is an Associate Professor of Information Systems at Southern Illinois University at Carbondale. Dr. Pearson has published over seventy articles in journals such as the Communications of the ACM, Information \& Management, Journal of Strategic Information Systems, Journal of Information Systems, Journal of Computer Information Systems, Decision Support Systems, Review of Business, Information Resources Management Journal and Public Administration Quarterly. His research interests are in the areas of technology adoption, ecommerce, management of quality, and IT project management. E-mail: jpearson@business.siuc.edu

Dr. Tammy Bahmanziari is an Assistant Professor of Accounting Middle Tennessee State University. Dr. Bahmanziari has published papers in the International Journal of Accounting Information Systems, Journal of Accountancy, Journal of Computer Information Systems and others. Dr. Bahmanziari's major research interests are in behavioral issues in accounting, ecommerce research and XBRL. E-mail: tammy.bahmanziari@mtsu.edu

\section{REFERENCES}

1. AACSB International. 2003. Sustaining scholarship in business schools - report of the doctoral faculty commission to AACSB International's board of directors Available at: http://www.aacsb.edu/publications/

2. American Accounting Association (AAA). 2008. Accounting faculty in U.S. colleges and universities: Status and trends Available at: http://www.iasplus.com/usa/0803accountingfaculty.pdf

3. Allen, T. and L. Ebby. 2004. Factors related to mentor reports of mentoring functions provided: Gender and relational characteristics. Sex Roles 50(2), pp. 129-139. 
4. Anderson, E. 2002. The new professoriate: Characteristics, contributions, and compensation. (Washington, DC: American Council on Education).

5. Baron, R., and A. Kenny. 1986. The moderator-mediator variable distinction in social psychological research: Conceptual, strategic, and statistical considerations, Journal of Personality and Social Psychology 51(6), pp. 1173-1182.

6. Basu, R., and S. Green. 1995. Subordinate performance, leader-subordinate compatibility, and exchange quality in leader-member dyads: A field study. Journal of Applied Social Psychology 25(1), pp. 77-92.

7. Behn, B., Carnes, G., Krull Jr., G., Stocks, K, and M. Reckers. 2008. Accounting Doctoral Education-2007 A Report of the Joint AAA/APLG/FSA Doctoral Education Committee. Issues in Accounting Education 23(3), pp. 357-367.

8. Blackburn, R., Chapman, D, and S. Cameron. 1981. Cloning in academics: Mentorship and academic careers. Research in Higher Education 15(4), pp. 315-327.

9. Blau, P. 1964. Exchange and power in social life. (New York: Wiley).

10. Boice, R. 1992. Lessons learned about mentoring. In M. D. Sorcinelli \& A. E. Austin (Ed.) Developing New and Junior Faculty. pp. 51-62. (San Francisco, CA: Jossey-Bass).

11. Bouillon, M. and S. Ravenscroft. 2010. Undergraduate preparation and dissertation methodologies of accounting PhDs over the past 40 years. Global Perspectives on Accounting Education 7, pp. 19-29.

12. Bowen, W. and N. Rudenstien. 1992. In Pursuit of the Ph.D. (Princeton, NJ: Princeton University Press).

13. Broverman, I., Vogel, S., Broverman, D., Clarkson, F., and P. Rosenkrantz. 1972. Sex role stereotypes: A current appraisal. Journal of Social Issues 28, pp. 59-78.

14. Cook, M., and A. Swanson. 1978. The interaction of student and program variables for the purpose of developing a model for predicting graduation from graduate programs over a 10-year period. Research in Higher Education 8(1), pp. 83-91.

15. Dansereau, F., Graen, G., and W. Haga. 1975. A vertical dyad linkage approach to leadership within formal organizations: A longitudinal investigation of the role making process. Organizational Behavior and Human Performance 13(1), pp. 46-78.

16. de Valero, Y. 2001. Departmental factors affecting time-to-degree and completion rates of doctoral students at one land-grant research institution. The Journal of Higher Education 72(3), pp. 341-367.

17. Eagly, A. 1987. Sex differences in social behavior: A social-role interpretation. (Hillsdale, NJ: Erlbaum).

18. Ensher, E. and S. Murphy. 1997. Effects of race, gender, perceived similariy, and contact on mentoring relationships. Journal of Vocational Behavior 50(3), pp. 460-481.

19. Gernster, C. and D. Day. 1997. Meta-analytic review of leader-member exchange theory: Correlates and construct issues. Journal of Applied Psychology 6, pp. 827-844.

20. Girves, J. and V. Wemmerus. 1988. Developing Models of Graduate Student Degree Progress. Journal of Higher Education, 59(2), pp. 163-189.

21. Glover, S., Prawitt, G., and D. Wood. 2006. Publications records of faculty promoted at the top 75 accounting research programs, Issues in Accounting Education 21(3), pp. 195-218.

22. Goertzen, B. and S. Fritz. 2004. Does sex of dyad members really matter? A review of leader-member exchange. Journal of Leadership Education 3(2), pp. 3-18.

23. Golde, C. and T. Dore. 2001. At cross purposes: What the experiences of today's doctoral students reveal about doctoral education. Available at http://www.phd-survey.org

24. Graen, G. 1976. Role-making processes within complex organizations. In M. D. Dunnette (Ed.), Handbook of industrial and organizational psychology. (Chicago, IL: Rand-McNally).

25. Graen, G. and T. Scandura. 1984. Moderating effects of initial leader-member exchange status on the effects of a leadership intervention. Journal of Applied Psychology 69(3), pp. 428-436.

26. Graen, G. and M. Uhl-Bien 1995. Relationship-based approach to leadership: Development of leadermember exchange (LMX) theory of leadership over 25 years: Applying a multi-level multi-domain perspective. Leadership Quarterly 6(2), pp. 219-247.

27. Green, S. and T. Bauer. 1995. Supervisory mentoring by advisors: Relationships with doctoral student potential, productivity, and commitment. Personal Psychology 48(3), pp. 537-562.

28. Groves, R, Fowler, F., Couper M., Lepkowski, J., Singer, E. and R. Tourangeau. 2004. Survey methodology. (Hoboken, NJ: Wiley).

29. Hermanson, D. 2008. What I have learned so far: Observations on Managing an Academic Accounting Career. Issues in Accounting Education 23(2), pp. 53-66. 
30. Hunter, D. and G. Kuh. 1987. The "write wing: Characteristics of prolific contributors to the higher education literature. Journal of Higher Education 58(4), pp. 443-462.

31. Kimmel, M. 2004. The Gendered Society. (New York, NY: Oxford UP).

32. Klein, K. And J. Kim. 1998. A field study of the influence of situational constraints, leader-member exchange, and goal commitment on performance. Academy of Management Journal 41(1), pp. 88-95.

33. Koberg, C., Boss, R., and E. Goodman. 1998. Factors and outcomes associated with mentoring among health-care professionals. Journal of Vocational Behavior 53(1), pp. 58-72.

34. Kram, K. 1983. Phases of the mentor relationship. Academy of Management Journal 26(4), pp. 608-625.

35. Leach, J., Loroz, W., Melicher, R., and R. Wermers. 2007. Research productivity in finance academia: Mentoring versus peer coauthorship. Unpublished Working Paper found at: http://69.175.2.130/ finman/Orlando/Papers/FMAMentoringStudy07.pdf

36. Linden, R., Sparrowe, R., and S. Wayne. 1997. Leader-member exchange theory: The past and potential for the future. Research in Personnel and Human Resources Management (15), pp. 47-119.

37. Lovitts, B. 2001. Leaving the Ivory Tower: The Causes and Consequences of Departure From Doctoral Study. (New York, NY: Rowman and Littlefield Publishers).

38. Nagy, M. 2002. Using single-item approach to measure facet job satisfaction. Journal of Occupational and Organizational Psychology 76, pp. 781-87.

39. Noland, T., Francisco, B., and D. Sinclair. 2007. Pursuing a PhD in accounting: What to expect. The CPA Journal 66(3), pp. 66-68.

40. Pedhauzur, E., and L. Schmelkin. 1991. Measurement, design, and analysis. (Hillsdale, NJ: Lawrence Erlbaum).

41. Plumlee, R., Kachelmeier, S., Madeo, S., Pratt, J., and G. Krull. 2006. Assessing the Shortage of Accounting Faculty. Issues in Accounting Education 21(2), pp. 113-125.

42. Ragins, B. 1997. Diversified mentoring relationships in organizations: A power perspective. Academy of Management Review 22(2), pp. 482-521.

43. Ragins, B. and J. Cotton. 1991. Easier said than done: Gender differences in perceived barriers to gaining a mentor. Academy of Management Journal 34, pp. 939-951.

44. Ragins, B. and J. Cotton. 1999. Mentor functions and outcomes: A comparison of men and women in formal and informal mentoring relationships. Journal of Applied Psychology 84, pp. 529-550.

45. Sackett, P., and J. Larson. 1990. Research strategies and tactics in industrial and organizational psychology. In M. Dunnett and L. Hough (Ed.), Handbook of industrial and organizational psychology. (Palo Alto, CA: Consulting Psychologists Press).

46. Schein, V. 1973. The relationship between sex role stereotypes and requisite management characteristics. Journal of Applied Psychology 57(2), pp. 95-100.

47. Schriesheim, C., Castro, S., and C. Cogliser. 1999. Leader-member exchange (LMX) research: A comprehensive review of theory, measurement, and data-analytic practices. Leadership Quarterly 10(1), pp. 63-113.

48. Sosik, J. and V. Godshalk. 2000. The role of gender in mentoring: Implications for diversified and homogeneous mentoring relationships. Journal of Vocational Behavior 57(1), pp. 102-122.

49. Tsui, A. and C. O'Reilly. 1989. Beyond simple demographic effects: The importance of relational demography in superior-subordinate dyads. Academy of Management Journal 32(2), pp. 402-423.

50. Ugrin, J., Odom, M. and J. Pearson 2008. Exploring the Importance of Mentoring for New. Scholars: A Social Exchange Perspective. Journal of Information Systems Education 19(3), pp. 343-350.

51. Wanous, J., Reichers, A., and M. Hurdy. 1997. Overall job satisfaction: How good are single-item measures? Journal of Applied Psychology 82, pp. 247-52.

52. Weiss, C. 1981. The development of professional role commitment among graduate students. Human Relations 34(1), pp. 13-31.

53. Zhao, C., Golde, C., and A. McCormick 2007. More than a Signature: How advisor choice and advisor behaviour affect doctoral student satisfaction. Journal of Further and Higher Education 31(3), pp. 263-281. 


\section{APPENDIX A: Survey Items for the Primary Variables of Interest}

LMX (Scale for New Faculty) (Derived from Graen and Uhl-Bien 1995) - Five item, five-point likert scale measuring the new faculty members' evaluation of their relationship with their chairs.

1. Did you know where you stood with your advisor; did you usually know how satisfied your advisor was with what you did?

2. How well did your advisor understand your problems and needs?

3. How well did your advisor recognize your potential?

4. How would you characterize your working relationship with your advisor?

5. To what extent could you count on your advisor to "bail you out" at his or her expense when you really needed it?

LMX (Scale for Chair) (Derived from Graen and Uhl-Bien 1995) - Five item, five-point likert scale measuring the chair's evaluation of his/her relationship his/her former student.

1. Did you know where you stood with this student; did you usually know how satisfied this student was with what you did?

2. How well did this student understand your problems and needs?

3. How well did this student recognize your abilities?

4. How would you characterize your working relationship with this student?

5. To what extent could you count on this student to "bail you out" at his or her expense when you really needed it?

Years_To_Degree (Efficiently Completing Doctoral Program) - One item measuring years to Ph.D.

1. How long did it take you to finish your $\mathrm{PhD}$ (input the number of months between the time you enrolled and were officially awarded your $\mathrm{PhD}$ )?

Publications (Effectively Performing Scholarly Activity) - One item measuring number of publications.

1. How many publications in blind peer reviewed journals did you have in your first six years of academic employment after receiving your $\mathrm{PhD}$ (input the number of publications)?

Value (Value in Chair's Ability to Assist in Advancing Research) - One seven point item

1. While you were in your first six years of academic employment, how valuable did you think your chair would be toward helping you advance your research agenda? What were your thoughts at the time? (1 Not Valuable to 7 - Highly Valuable)

Collaboration - One item

1. How many research studies did you collaborate on with your dissertation chair while you were working on your $\mathrm{PhD}$ ? (enter the number)

Continue (Continuation of the Mentor Relationship) - One seven point item

1. How much did the relationship between you and your mentor continue during your first six years of academic employment? (1 - Did Not Continue to 7 - Continued a Great Deal) 


\section{APPENDIX B: Correlation Matrix}

\begin{tabular}{|c|c|c|c|c|c|c|c|c|}
\hline & Publications & $\mathbf{L m x}$ & Collaborate & Job_Type & Committee & Chair_Pubs & Value & Continue \\
\hline Publications & 1 & & & & & & & \\
\hline Lmx & $\begin{array}{l}.411 \\
.008\end{array}$ & 1 & & & & & & \\
\hline Collaborate & $\begin{array}{l}.420 \\
.006\end{array}$ & $\begin{array}{l}.451 \\
.003\end{array}$ & 1 & & & & & \\
\hline Job_Type & $\begin{array}{l}.410 \\
.008\end{array}$ & $\begin{array}{l}.156 \\
.329\end{array}$ & $\begin{array}{l}.079 \\
.624\end{array}$ & 1 & & & & \\
\hline Committee & $\begin{array}{r}-.290 \\
.066\end{array}$ & $\begin{array}{l}-.342 \\
.029\end{array}$ & $\begin{array}{r}-.120 \\
.374 \\
\end{array}$ & $\begin{array}{l}-.156 \\
.329 \\
\end{array}$ & 1 & & & \\
\hline Chair_Pubs & $\begin{array}{l}.385 \\
.013\end{array}$ & $\begin{array}{l}.096 \\
.549\end{array}$ & $\begin{array}{l}.141 \\
.378\end{array}$ & $\begin{array}{l}.163 \\
.310\end{array}$ & $\begin{array}{c}-.133 \\
.407\end{array}$ & 1 & & \\
\hline Value & $\begin{array}{l}.483 \\
.001\end{array}$ & $\begin{array}{l}.397 \\
.011\end{array}$ & $\begin{array}{l}.227 \\
.154\end{array}$ & $\begin{array}{l}.103 \\
.520\end{array}$ & $\begin{array}{c}-.159 \\
.321\end{array}$ & $\begin{array}{l}.161 \\
.313\end{array}$ & 1 & \\
\hline Continue & $\begin{array}{l}.365 \\
.019 \\
\end{array}$ & $\begin{array}{l}.303 \\
.054\end{array}$ & $\begin{array}{l}.217 \\
.173 \\
\end{array}$ & $\begin{array}{l}.222 \\
.164\end{array}$ & $\begin{array}{l}-.238 \\
.133\end{array}$ & $\begin{array}{l}.122 \\
.448 \\
\end{array}$ & $\begin{array}{l}.421 \\
.006\end{array}$ & 1 \\
\hline
\end{tabular}

${ }^{(*)}$ Correlation is significant at the 0.05 level (2-tailed).

${ }^{(* *)}$ Correlation is significant at the 0.01 level (2-tailed).

(a) $\mathrm{N}=41$

Publications - The number of peered reviewed publications the new faculty member had in his or her first six years of academic employment.

LMX - Leader member exchange.

Collaborate - The number of research projects collaborated on beyond the dissertation during the $\mathrm{PhD}$ program.

Job_Type - The type of university the new faculty member was primarily employed at during his or her first six years of academic employment ( $\mathrm{PhD}$ granting or Non-PhD granting).

Committee - The number of committee assignments the new faculty member served on during his or her first six years of academic employment.

Chair_Pubs - The chair's average number of publications (in publications per year).

Value - The degree to which the new faculty member valued the chair's ability to advance the new faculty member's research program.

Continue - The degree to which the relationship between the new faculty member and the chair continued beyond the $\mathrm{PhD}$ program. 
NOTES 